Section Editor

John J. Millichap, MD

\title{
Teaching NeuroImages: \\ Diagnosis
}

Meningioma and...

Diane Wang, BS*

Shaminta Hamindian* Jerome B. Posner, MD Robert J. Young, MD

Correspondence to

Dr. Young:

youngr@mskcc.org
A previously healthy 64-year-old woman experienced rapidly progressing dysphasia, dementia, dystonia, and diplopia. A $4.5-\mathrm{cm}$ frontotemporal meningioma was found on imaging (figure) and she was scheduled for surgery. Because her symptoms were not consistent with the meningioma location, ${ }^{1}$ imaging was reviewed further. Presumptive diagnosis of Creutzfeldt-Jakob disease (CJD) was made and surgery for that afternoon was cancelled. Autopsy 1 month later demonstrated prion protein scrapie (PrPsc), confirming CJD. The meningioma presented a potential satisfaction-of-search error. Surgery would have risked infection to those exposed, as PrPsc is highly resistant to denaturation even at autoclave temperatures. ${ }^{2}$

\section{AUTHOR CONTRIBUTIONS}

Diane Wang: drafting/revising the manuscript, analysis or interpretation of data, accepts responsibility for conduct of research and final approval. Shaminta Hamidian: drafting/revising the manuscript, analysis or interpretation of data, accepts responsibility for conduct of research and final approval, acquisition of data, study supervision. Jerome B. Posner: analysis or interpretation of data, accepts responsibility for conduct of research and final approval, acquisition of data. Robert J. Young: drafting/revising the manuscript, study concept or design, analysis or interpretation of data, accepts responsibility for conduct of research and final approval, acquisition of data, study supervision.

\section{STUDY FUNDING}

No targeted funding reported.

\section{DISCLOSURE}

The authors report no disclosures relevant to the manuscript. Go to Neurology.org for full disclosures.

\section{REFERENCES}

1. Proulx A, Strong M, Nicolle D. Creutzfeldt-Jakob disease presenting with visual manifestations. Can J Ophthalmol 2008;43:591-595.

2. LeBrun M, Huang H, Li X. Susceptibility of cell substrates to PrPSc infection and safety control measures related to biological and biotherapeutical products. Prion 2008;2:17-22.

\section{Figure Meningioma presents potential for satisfaction-of-search error}
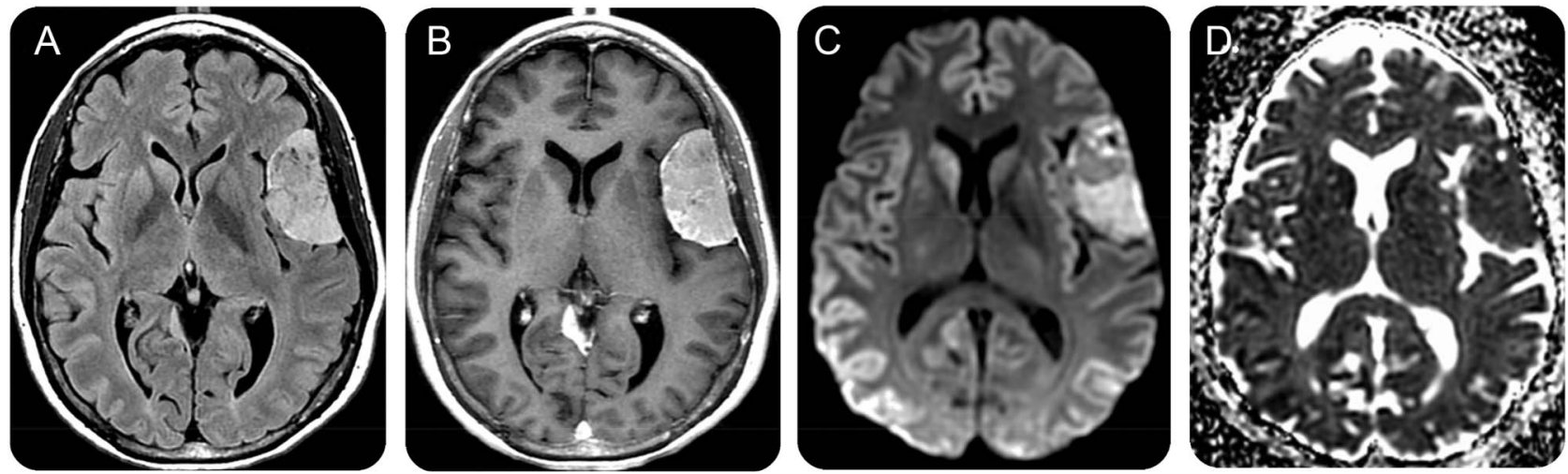

Axial (A) fluid-attenuated inversion recovery (FLAIR), (B) contrast T1, (C) diffusion-weighted imaging, and (D) apparent diffusion coefficient images show an enhancing meningioma along the left frontotemporal convexity with mild diffusion restriction due to hypercellularity. There are also bilateral FLAIR hyperintense diffusion-restricted lesions in the basal ganglia, temporal, and occipital lobes with classic cortical ribbon pattern, consistent with Creutzfeldt-Jakob disease.

Download teaching slides: Neurology.org

*These authors contributed equally as co-first authors.

From the Departments of Radiology (D.W., S.H., R.J.Y.) and Neurology (J.B.P.), Memorial Sloan Kettering Cancer Center, New York, NY. 


\section{Neurology}

Teaching NeuroImages: Diagnosis: Meningioma and...

Diane Wang, Shaminta Hamindian, Jerome B. Posner, et al.

Neurology 2017;88; 157

DOI 10.1212/WNL.0000000000003813

This information is current as of April 10, 2017

\begin{tabular}{|c|c|}
\hline $\begin{array}{l}\text { Updated Information \& } \\
\text { Services }\end{array}$ & $\begin{array}{l}\text { including high resolution figures, can be found at: } \\
\text { http://n.neurology.org/content/88/15/e157.full }\end{array}$ \\
\hline Supplementary Material & $\begin{array}{l}\text { Supplementary material can be found at: } \\
\text { http://n.neurology.org/content/suppl/2017/04/11/WNL.0000000000003 } \\
\text { 813.DC1 }\end{array}$ \\
\hline References & $\begin{array}{l}\text { This article cites } 2 \text { articles, } 0 \text { of which you can access for free at: } \\
\text { http://n.neurology.org/content/88/15/e157.full\#ref-list-1 }\end{array}$ \\
\hline Subspecialty Collections & $\begin{array}{l}\text { This article, along with others on similar topics, appears in the } \\
\text { following collection(s): } \\
\text { Cognitive neuropsychology in dementia } \\
\text { http://n.neurology.org/cgi/collection/cognitive_neuropsychology_in_de } \\
\text { mentia } \\
\text { MRI } \\
\text { http://n.neurology.org/cgi/collection/mri } \\
\text { Primary brain tumor } \\
\text { http://n.neurology.org/cgi/collection/primary_brain_tumor } \\
\text { Prion disease; see Infections/prion } \\
\text { http://n.neurology.org/cgi/collection/prion_disease }\end{array}$ \\
\hline Permissions \& Licensing & $\begin{array}{l}\text { Information about reproducing this article in parts (figures,tables) or in } \\
\text { its entirety can be found online at: } \\
\text { http://www.neurology.org/about/about_the_journal\#permissions }\end{array}$ \\
\hline Reprints & $\begin{array}{l}\text { Information about ordering reprints can be found online: } \\
\text { http://n.neurology.org/subscribers/advertise }\end{array}$ \\
\hline
\end{tabular}

Neurology ${ }^{\circledR}$ is the official journal of the American Academy of Neurology. Published continuously since 1951, it is now a weekly with 48 issues per year. Copyright @ 2017 American Academy of Neurology. All rights reserved. Print ISSN: 0028-3878. Online ISSN: 1526-632X.

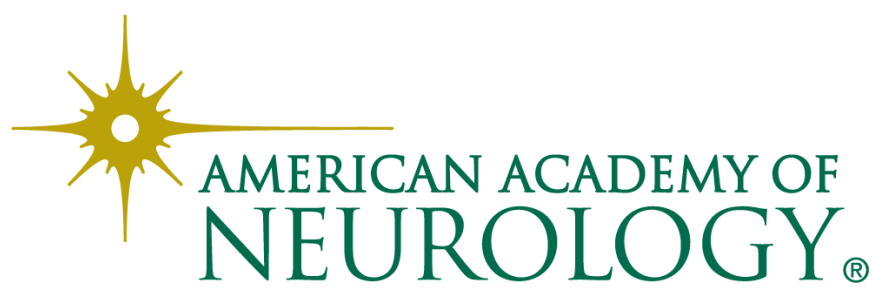

